\title{
Board Characteristics and Earnings Quality of Listed Conglomerate Firms in Nigeria
}

\author{
Daddau Haruna \\ Department of Accounting, \\ Kaduna State University, Kaduna-Nigeria \\ Lubabatu Mansur Kwambo, $\mathrm{PhD}$ \\ Department of Accounting, \\ Kaduna State University, Kaduna-Nigeria \\ Shehu Usman Hassan, PhD \\ Department of Accounting, \\ Kaduna State University, Kaduna-Nigeria
}

\begin{abstract}
This study examines the effect of Board Characteristics on Earnings Quality of Nigeria Conglomerate firms. Data were extracted from the audited accounts of Nigeria conglomerate firms using secondary source of data collection. Two step regression was employed in analyzing the data extracted. The result indicated that the board characteristics proxies have a significant impact on earnings quality of Nigerian Conglomerate firms. This establishes the fact that board characteristics play a significant role in checkmating the unethical behaviours of managers in the Nigerian conglomerate firms and thus improving the earnings quality. The study therefore, recommends that the proportion of non executive directors should be maximized. Emphases should be on experience and objectivity when appointing women as members on board of directors not by mere quest for gender sensitivity. The implication of the findings is that firm with higher number of non executive and women directors are more likely to report quality earnings.
\end{abstract}

KEYWORDS: Board Characteristics, Earnings Quality, Conglomerate firms, Nigeria. 


\section{Introduction}

As Nigeria continues to aspire to become one of the top 20 economies in the world by the year 2020, one important issue that remains on the front burner is how to build investors' confidence in the domestic economy through good Corporate Governance and transparent financial reporting. The tragic collapses and scandals of giant firms such as the WorldCom, Xerox, and Enron Corporation highlights the critical need to focus on the anchors of sound Corporate Governance both in developed and developing countries. The bankruptcy of these giants inarguably stemmed from earnings manipulation due to fraudulent practices by the board of directors and weak governance mechanisms in place. Consequently, many shareholders lost their confidence in the affected firms and major players globally. Seemingly, Corporate Governance regulations turned out to be the most significant tool to regaining the lost confidence (Fodio, Ibikunle and Chiedu 2013).

Limited access to managerial information causes the providers of finance such as shareholders and debt holders to heavily rely on the financial statement of firms. As financial reporting provides value-relevant information to the external parties of the organization, the heavy reliance placed on accounting numbers create powerful incentives for managers to manipulate earnings to their own advantage. Hence, it is important for financial accounts to provide the truthfulness and accuracy of financial information to enable the shareholders to make decisions wisely. The lack of accuracy in the financial results will lead to the shareholders and other users making wrong judgments and decisions (Dalhat, 2014).

Fama and Jensen (1983) argued that the role of the board of directors is to protect shareholder interests by monitoring the firm's management. An important factor that may affect the board's ability to monitor the firm's managers is its composition. In the agency theory framework, non-executive directors have an incentive to avoid colluding with managers because the value of non executive directors' human capital is partially determined by the effectiveness of their monitoring performance. Since the board of director is vested with the responsibility of monitoring the interest of shareholders, they ought to have greater interest in the appointment of directors to ensure that qualified, experienced and educated directors are appointed (Akpan \& Amran, 2014).

Sanda, Mikailu and Garba (2005) observed that the need for a study of this nature is even more important in an environment like Nigeria, which is characterized with growing calls for effective corporate governance and financial reporting, particularly for public limited liability companies.

It will be timely to carry out a study on board characteristics and earnings quality of listed conglomerate firms in Nigeria by providing empirical evidence to address the uncertainty surrounding directors (non executive, women, foreign and board size) of conglomerate firm's ability to protect the interest of stakeholders by preventing earnings management and increasing earnings quality. This study is thus geared at unfolding the possible relationships that exist between the board characteristics and earnings quality with special reference to the Nigerian Conglomerate Firms. The choice of conglomerate firm is due to its unique characteristics of producing diverse products and also studies in this manufacturing subsector of the economy are limited.

The major objective of the study is to ascertain the level to which Board Characteristic influences the Earnings Quality of Nigerian conglomerates firms. Therefore for the purpose of this study, the following specific objectives are set out below:

i. to examine the impact of non executive directors on earnings quality of Nigerian conglomerates firms ;

ii. to investigate the influence of women directors on earnings quality of Nigerian conglomerates firms ;

iii. to determine the contribution of foreign director on earnings quality of Nigerian conglomerates firms ; 
iv. to ascertain the impact of board size on earnings quality of Nigerian Conglomerate firms

The following null hypotheses were formulated in concordance with the specific objectives of the study to test the influence of board characteristics on earnings quality of Nigerian conglomerates firms.

$\mathrm{H}_{\mathrm{O} 1}$ non executive directors have no significant impact on earnings quality of Nigerian conglomerates firms.

$\mathrm{H}_{\mathrm{O} 2}$ women directors have no significant influence on earnings quality of Nigerian conglomerates firms.

$\mathrm{H}_{\mathrm{O} 3}$ foreign directors have no significant contribution on earnings quality of Nigerian conglomerates firms.

$\mathrm{Ho}_{4}$ board size has no significant effect on earnings quality of Nigerian Conglomerate Firms

The theoretical and practical contributions of this sturdy include but not limited to providing empirical evidence on the impact of board characteristics on earnings quality in Nigeria conglomerate firms, it will also provide information to policy makers such as Security and Exchange Commissions (SEC) who are concerned with corporate governance assessment and administration. Again it will serve as a good reference material to academicians and practitioners who may undertake research in the area.

The findings of the study is expected to guide the policy makers of the conglomerate firms in embarking on crucial and fruitful decisions towards investment and management of human and material resources by ensuring proper selection of directors among non executive, women, foreign and board size.

The rest of the paper is divided into four sections covering discussion on the literature review and theoretical framework, the research method and model specification, result and discussions and conclusion and recommendation.

\subsection{Literature Review and Theoretical Framework}

This section discusses the related and relevant literature of the study. The items discussed consist of empirical review of non executive directors and earnings quality, women directors and earnings quality, foreign directors and earnings quality and finally board size and earnings quality. The theoretical framework was also captured.

\subsubsection{Non Executive Directors and Earnings Quality}

There are two views on this issue of board composition - those who argue for more nonexecutive directors on boards and those who favour more executive directors on boards. For those who support more non-executive directors on the board based their arguments on two theories; agency and resource dependency. An important question of board composition concerns the ideal combination of outside and inside members. Outsiders are more independent of a firm's CEO, but are potentially less informed regarding firm projects than insiders. Insiders are better informed regarding firm projects, but have potentially distorted incentives deriving from their lack of independence from the firm's CEO (Hannifa and Cooke, 2002). Fama and Jensen (1983) argued that the inclusion of outside directors increases the board's ability to be more efficient in monitoring the top management and to ensure there is no involvement of top managers to expropriate stakeholders wealth as the incentive to develop their reputation as experts in decision control. The Malaysian code of CG related that good CG rests firmly with BOD and the code requires one third of the board to comprise independent non-executive directors in order to bring an independent judgment on the decision process (Hashim and Devi, 2010).

Muravyev, A., Talavera, O. \& Weir, C. (2016), studied the effect on company performance of appointing non-executive directors that are also executive directors in other firms. The analysis is based on a new panel data set of UK companies over 2002-2008. Findings 
suggested a positive relation between the presence of these non-executive directors and the accounting performance of the appointing companies. The effect is stronger if these directors are executive directors in firms that are performing well. They also found a positive effect when these non-executive directors are members of the audit committee. Overall, the results are broadly consistent with the view that non-executive directors that are executives in other firms contribute to both the monitoring and advisory functions of corporate boards. However, this study suffered a serious weakness as data extracted did not exceed 2010, for that events and changes in the country economic focus may have rendered the findings invalid.

Smith (2015), investigated whether corporate governance initiatives in South Africa that relate to the monitoring ability of the non-executive directors on the board of small and medium companies have improved earnings quality by adopting conservative accounting practices. The sample construct includes the $2008-2011$ reporting periods of South African companies listed on the Alternative Exchange (AltX). A reverse regression of earnings on returns was used to examine the market-based attributes of earnings quality, i.e. conservatism and the timeliness of earnings. No evidence was found that the boards of small and mediumsized companies are inclined to adopt conservative accounting practices that will result in the asymmetric timeliness of earnings. There is also no evidence that the quality of reported earnings improved as a result of the monitoring ability of the board with reference to the representation of non-executive directors on the board.

Kamaruzaman, Mazlifa, and Maisarah (2009), provided evidence for the transparency level on income statements with regards of firmse characteristics of 150 main and second boards companies listed on the Bursa Malaysia. The characteristics were grouped into three groups of variables: structural (firm size, leverage and number of shareholder), market related (listing type and industry type) and performance (profit margin, return on equity and liquidity). The study was started with the development of a Transparency Index based on the percentage of the details of expenses disclosed in annual reports (notes to the accounts) over the total expenses of the company. The findings suggested that this index on the average for the companies in the sample is about $64 \%$ with three companies scoring transparency index of $100 \%$. Both univariate and multivariate statistical analysis were performed on the data. The stepwise regression method indicated that only one variable was significant at $5 \%$ which was the Number of Shareholders (LnNOSH). The other factors were not significant. A major difficulty in determining the total expenses are cost of ambiguous nature of certain expense item disclosure. For example, depreciation expense is not clearly identified as to whether it is in the cost of goods sold, selling and administration expenses and many others. In addition, the cost of sales may also lead to bias for non-manufacturing and trading companies, that is the service industries. Therefore, the item cost of sales or cost of goods sold is excluded from the total expenses. Hence, this is the major limitation of the income statements transparency index constructed and used in this study.

Adelopo (2010) examined voluntary disclosure practices among listed companies in Nigeria. Results from Univariate and Multivariate analyses of listed companies, representing $41 \%$ of the population studied, suggest an average voluntary disclosure of $44 \%$ based on modified Meek, Roberts \& Gray (1995) disclosure index comprising 24 disclosure items. The study found significant positive relationship between voluntary disclosure and firm size. Significant positive relationship was also found between market based definition of firm performance and voluntary disclosure. Percentage of block share ownership and percentage of managerial share ownership were found to be negatively related to firm disclosures. This study was conducted using the Code of Corporate Governance 2003. The adoption of the Code of Corporate Governance 2011 may affect the outcome of the result.

Adebimpe and Peace, (2011) examined the association between corporate governance, company attributes and voluntary disclosures among Nigerian listed companies. In order to examine this association, two disclosure indexes were built using a sample of 50 listed companies in Nigeria. The first index contains twenty items which are mandatory according to a number of selected IFRSs but which are voluntary in Nigeria for the year 2008. The second index contains sixty voluntary accounting and non-accounting items. The study uses univariate, multivariate and cross-section models to explore the relationship between each disclosure index and corporate attributes. The corporate attributes are the independent 
variables comprising corporate governance and company characteristics. The results of the regression analysis reveal that only board size has a significant positive relationship with the extent of voluntary disclosures on the sample companies. The Board composition is statistically positive and insignificant impact on disclosures. The effect of Board ownership is positive for IFRS disclosures but negative and insignificant for Non-IFRS disclosures while sector is negative for both disclosures but has a significant effect on Non-IFRS disclosures. The limitations encountered in this study include the insufficient weighting of scores for disclosure criteria in the sense that companies were awarded 1 for disclosure of an item and 0 for non-disclosure without considering the depth of the disclosure of such item in the annual report. Also, the inability to access annual reports covering longer periods rather than just a year inhibits the generalization of the findings to an extent.

Additionally, study by Abdullah and Mohammed (2004) and Abdulrahman and Mohammed (2006) did not also find any significant evidence between independence of boards and earnings management in the Malaysian firms. This may be as a result of non - inclusion of financial firms in their sample. Furthermore, study by Jaggi \& Leung (2007) provided evidence of insignificant relationship between proportions of non-executive directors and accrual quality in high family-ownership samples of Hong Kong listed firms which suggest that the monitoring effectiveness of independent directors is reduced in family controlled firms. The result may be different if the study includes other firms not only family controlled firms because the independent directors are selected base on merit rather than family consideration.

\subsubsection{Women Directors and Earnings Quality}

Gender diversity in the boards is also supported by different theoretical perspectives. For example, agency theory which is mainly concerned about independence of directors and a balance between executive and non-executive directors on boards. Representation from diverse groups will provide a balanced board so that no individual or small group of individuals can dominate the decision-making of the board (Hampel, 1998). Further, diversity also provides representation for different stakeholders of the firm for equity and fairness (Keasey, Thompson, and Wright 1997). From resource dependency perspective, the board is a strategic resource, which provides a linkage to various external resources (Ingley \& van der Walt, 2001). This is facilitated by board diversity. Many scholars now believe that an increase in board diversity leads to better boards and governance on the ground that diversity allows boards to tap on broader talent pools for the role of directors (Pearce \& Zahra, 1991; Burke, 1997; Daily, Certo \& Dalton, 1999; Singh \& Vinicombe, 2004).

Gender diversity has drawn the attention of various scholars (e.g., Van der Walt \& Ingley, 2003; Singh \& Vinicombe, 2004; Huse \& Solberg, 2006). Issues examined include: the reasons for fewer women on corporate boards (Singh \& Vinicombe, 2004); the predictors of both organisational and outside forces for women on boards (Burke, 2000); and women directors and managers' experiences and perceptions of their role (Burke \& Mattis, 2000; Huse \& Solberg, 2006; Jamali, Safieddine \& Daouk, 2007).

In corporate world, women representation on boards is very limited. According to Catalyst census, women directorship is only 12.4 per cent in the US and 6.4 in the UK; the percentage of executive directors is 2 percent in both countries (Singh \& Vinnicombe, 2004). In Canadian boards, women representation was less than 5 percent (Burke, 1997). Daily, Certo and Dalton (2000) have also found similar results in US, with meager, but a growing level of representation for women in the boardroom. Further, 86 per cent of CEOs consider female representation on boards as very important for their organizations (Mattis, 2000).

Some studies suggested that most of the women directors are usually outsiders and from noncorporate field (Hillman, Cannella \& Harris, 2002). They are also likely to possess managerial skills such as legal, human resources, communications, public relations rather than line functions of operations, marketing, compared to men (Zelechowski \& Bilimoria, 2004). Further, scholars have argued that it makes good business sense to have women on board as "60 per cent of all purchases [in the US] are made by women" (Daily, Certo \& Dalton,1999). 
Study conducted by Smith, Smith and Verner (2006) found that women on board of directors have significant positive effect on firm performance. With most of them having non-corporate background, women are far more likely to hold valuable, unique, and rare information because they have been excluded from the traditional development paths of corporate directorships. Letendre (2004) brings up the idea of 'value in diversity' and suggests that female board members will bring diverse viewpoints to the boardroom and will provoke lively boardroom discussions. Bilimoria and Wheeler (2000) suggested that, on an average female board member is younger than her male counterpart, and so the board benefits from infusion of new ideas and approaches to deliberations. Women may have different views, values and ways to express and communicate their opinions. As a result, women are more likely to question the conventional wisdom and to speak up when concerned about an issue or a particular managerial decision through more questioning and open discussion (Fondas \& Sassalos, 2000; Huse \& Solberg, 2006). Even if gender diversity causes disagreement, Latendre (2004) suggested that such disagreements are valuable to the board as it leads to better board dynamics and decision making.

Velte (2016) examined women on management board and their impact on environmental, social and governance (ESG) performance in two European two tier countries. The study covered a sample of German and Austrian companies which are listed at the Prime Standard of the Frankfurt and Vienna Stock Exchange for the business years 2010-2014 (1,019 firmyear observations). A correlation and regression analysis was conducted to measure a possible link between gender diversity and ESG performance in these European countries. Multiple regressions state that female members in the management board do have a positive impact on ESG performance. This study was conducted in advanced economies and Nigeria being an emerging economy provides genuine incentives for further investigation of this relationship.

Clikeman, Geiger \& O'Connell, (2001) surveyed accounting students to determine whether gender or nationality impacts on attitudes toward common techniques used to manage reported earnings. They use responses to hypothetical situations to determine attitudes toward earnings management behavior and find no significant differences in the attitudes of men and women.

Al-Hayale and Lan (2004) question a number of company managers and external auditors in Jordan to ascertain their views of income increasing and income decreasing earnings management techniques. They found no significant differences in the attitudes of men and women about earnings management. However, the limitation of these two studies is that they did not examine the actual behavior that is directly related to financial reporting or earnings quality. Krishnan and Parsons (2008), however, extend those studies by examining actual reported financial numbers and comparing the earnings quality in companies with higher percentages of women directors to those with fewer women on their boards. They examined a set of data that covers the period from 1996 to 2000 and use accounting conservatism as a measure for earnings quality. They found that companies with more female senior managers are more profitable and have higher stock returns after initial public offerings than those with fewer female in the management ranks. They use the Catalyst annual censuses of women as corporate officers and top earners for 353 of the Fortune 500 companies. They asserted that the improved performance for companies with more women senior executives is not produced through earnings management practice. Instead, they find that earnings quality is positively associated with gender diversity.

It is worth mentioning that the findings of previous studies may not apply in all countries. Kang, Cheng \& Stulz, (2007) argued that board diversity and independence findings may not extend across national boundaries due to different regulatory and economic environments, cultural differences, the size of capital markets and the effectiveness of governance mechanisms.

\subsubsection{Foreign Directors and Earnings Quality}

Due to sustained globalization, foreign ownership has become evident through major institutional shareholders around the world. For instance, foreign ownership accounted for 
$13.5 \% 24$ of U.S firm's total equity, $35.7 \%$ of U.K, $40.1 \%$ of France, $20.1 \%$ of Germany, and $26.7 \%$ of Japan as of 2006 (the KFSC 2007).

Alzoubi (2016) examined the association between internal corporate governance mechanism and earnings management of Jordanian companies. This study measured the magnitude of discretionary accruals as a proxy for earnings management using the cross-sectional modified Jones model. Ordinary least squares and generalized least squares were used to test the relationship between company ownership and earnings management, using a sample of 62 companies listed on the Amman Stock Exchange. The results revealed that foreign ownership have superior influence on financial reporting quality since it is, to a greater extent, potentially able to curtail earnings management. However the study suffered some deficiencies as the study is a cross sectional study that has nothing to do with the data heterogeneity and also concerned about serial correlation which the study did not considered. Thus our study is intended to be carried out using panel data which will give room for the test of hetroscedasticity and multicollinierity.

Dahlquist and Robertsoon (2001) argued that the extent of the deviation for foreign investors from holding the market portfolio is mostly similar to institutional investors. They found that foreign portfolio investors underinvested in firms with a dominant owner and invest more in large firms, firms paying low dividends, and firms with large cash position on their balance sheet in the Swedish market. Grinblatt and Keloharju (2000) reported that domestic investors are less sophisticated and take the opposite position to that of more sophisticated foreign investors in the Finnish market. They interpreted that foreign investors tend to pursue a momentum strategy but domestic investors seem to be contrarian. This result implies that foreign investors are sophisticated investors but are also transient institutional investors. Namely, the positive relationship between firm value (earnings quality) and foreign investors results from foreign investors' preference to specific firms not foreign investors' active monitoring incentives of a firm's management.

Olowookere \& Adebiye (2016) examined the relationship between Corporate Ownership Structure and Financial Reporting Quality among Deposit Money Banks in Nigeria. This study analyzed whether a firm's ownership structure (measured with three variables: managerial ownership, foreign ownership and institutional ownership) improves the quality of the financial reporting or not. Using a sample of all Deposit Money Banks listed on Nigeria Stock Exchange for nine years between 2005 and 2013, using Ordinary Least Square (OLS) Regression technique, the study found that discretionary accruals as a proxy for financial reporting quality is positively related to managerial ownership and relate negatively to institutional and foreign ownership. The study's result suggests that foreign ownership does not improve the quality of annual earnings by reducing the levels of financial reporting manipulation. The main drawback of this study is that the study concentrated in the Nigerian deposit money Banks, whereas the present study is on the conglomerate firms in Nigeria and is extend to 2015 financial year.

Similarly, Hooghiemstra, Hermes, Oxelheim \& Randoy (2016) examining the effects of the presence of a foreign board member on earnings management. Using a sample of 3,249 firmyear observations representing 586 non-financial listed Nordic firms during 2001-2008. The study found that the presence of a non-Nordic, foreign director is associated with significantly higher levels of earnings management. Moreover, it provided preliminary evidence that differences in accounting knowledge drive this effect. The results suggested that it may not necessarily be beneficial to appoint a foreign director to the board. This result may be as a result of non - inclusion of financial firms in their sample. Inclusion of financial firms may give a different result.

\subsubsection{Board Size and Earnings Quality}

Prior studies provide evidence on the role of board size in enhancing the monitoring of management. Monks and Minow (2004) suggested that larger boards are able to commit more time and effort, and smaller boards are able to commit less time and effort, to overseeing management. Klein (2002) extended this argument by suggesting that board monitoring is positively associated with larger boards due to their ability to distribute the work load over a 
greater number of observers. The majority of the previous literature supports this argument, by finding that larger boards are strongly associated with lower levels of earnings management (Bedard, J., Chtourou, S.M., \& Courteau, L., 2004, Chtourou and Courteau, 2004; Xie et al., 2003; Yu, 2008).

Xie et al. (2001) examined the characteristics of the board in constraining earnings management using discretionary current accruals using the Jones (1991) model to measure earnings management for a sample of 282 US firms for the years 1992, 1994 and 1996. Their results showed that earnings management is less likely to take place in firms with larger boards. Yu (2008) found that small boards seem more prone to failure to detect earnings management. One interpretation of this effect is that smaller boards may be more likely to be "captured" by management or dominated by blockholders, while larger boards are more capable of monitoring the actions of top management (Zahra and Pearce, 1989).

Ramachandian et al (2015) in examining the influence of corporate governance practices on earnings management analyzed the governance practices of 326 companies listed in the Singapore stock exchange by using the observations of two years. The structural model linking the corporate governance practices and EM through discretionary accruals were tested using Lisrel 9.1 student version. The study found among others that board independence, segregation of duties between the CEO and chairman, sizes of the audit committee and nomination committee have significant positive influence on board size and board size mediates the relationship between corporate governance practices (board independence, segregation of duties between CEO and chairman, audit committee size and nomination committee size) and EM through DAC implying that board size is crucial to effect better control. It concluded that segregation of responsibilities between the remuneration committee and the nomination committee, when the Board size is big, will reduce earnings management through. The outcome of this study may not be generalized because only two years observation was taking. Also our study intends to cover up to 2015.

Alotaibi \& Hussaine (2016) examined the practice of Corporate Social Responsibility (CSR) Disclosure in a Saudi Arabian context. This study has two particular objectives. First, it aims to measure the level of CSR disclosure quantity and quality. Second, it aims to investigate the determinants of CSR disclosure quantity and quality in a Saudi Arabian context. The study examined a sample from Saudi non-financial listed firms covering the period of 2013-2014. In addition, it develops CSR disclosure indices to measure the level of quantity and quality of CSR disclosure. The study found that Saudi Arabian firms provided higher levels of CSR disclosure quantity; however, the quality of the disclosure was relatively low. In addition, the study found that CSR disclosure quantity was positively associated with board size and the size of audit committee. However, it is negatively associated with percentage of governmental ownership and size of remuneration committee. In contrast, the quality of CSR disclosure was positively associated with the board size and the percentage of managerial ownership. However, the study found a negative association with the percentage of independent directors.

Abdul Rahman and Ali (2006) investigated the extent of the effectiveness of the board of directors, the audit committee and concentrated ownership in constraining earnings management among 97 Malaysian listed firms over the period 2002-2003. Their study revealed that earnings management is positively related to the size of the board of directors. Kao and Chen (2004) examined the relationship between board characteristics and earnings management in Taiwan. They found that large board size is related to a higher extent of earnings management. Their sample consists of 1,097 observations and they apply the crosssectional Jones model to measure earnings management.

Hence, both Abdul Rahman and Ali (2006) and Kao and Chen (2004) found a significant positive relationship between board size and the empirical indicator of earnings management. Both studies use the basic earnings management estimation method (Jones and modified Jones models respectively) that does not control for a firm's performance when estimating accruals. However, this may not be the reason for their conflicting results with the majority of the literature, as Xie et al. (2001) also used the Jones model but found a negative relationship between earnings management and board size. Their different results might be due to different 
types of earnings management adopted in these countries as discussed previously, or to the differences in markets and corporate governance practice that are revealed by these authors.

Considering the earlier discussion of the findings of Asian-based studies that board independence is less effective in constraining earnings management than in Anglo-American countries, and that large boards in some Asian studies show a positive association with earnings management, a further comment can be made. In less developed countries, boards may contain less effective independent directors because some may have been appointed through social connections rather than through ability and competition. In such boards, the advantages of size, namely the presence of more independent directors with valuable experience and diverse backgrounds, will be missing. Boards may be large in size but some outside directors may not be independent or very effective which in turn will demolish the effect of board size on quality of the earnings.

There are many theories in extant literatures that have been used to underpin research of this nature. These theories include stakeholder theory and agency theory. The agency theory is the one this research work is hinged on. Therefore, the study is based on the proposition of agency theory to link board characteristics and earnings quality. The theory is considered suitable. It involves a contract under which the principal (Owners) engages another party (Managers), called agent, to perform some services on their behalf, where some power of decision making are delegated to the agent (Jensen and Meckling, 1976). In the modern business world, the principal is the shareholders, who are the owners of the company, whereas the management of the company represents the agent.

\section{Methodology and Model Specification}

The study employed ex-post factor research design. The choice of this design is informed by the positivism framework, which assumes that social reality is singular, objective and independent. It also involves the use of deductive process with theories for the understanding and explanation of social phenomenon. Similarly, ex-post factor research design is chosen because the aim is to investigate the impact as well as the relationships between different components of board characteristics and earnings quality of Nigerian conglomerate firms, so as to establish the causal relationship or otherwise between them. The study used secondary data extracted from the published audited account of all listed conglomerate firms for ten years (2006-2015). The population of the study comprises of all the 6 conglomerate firms listed on the Nigerian Stock Exchange as at $31^{\text {st }}$ December, 2015. The study used the entire population as sample using censor sampling technique.

The techniques for analysis used in research are many but for the purpose of this research work, multiple regression analysis is adopted to estimate the model of the study. Panel data is used to account for individual heterogeneity of the sample firms. Two steps regression is adopted in determining the quality of earnings of the Nigerian listed conglomerate firms adopting modified Jones as in Francis, LaFond, Olsson and Schipper (2005) model. The residuals for the model after inserting the sampled firms' data represent earnings quality in the second regression model specified for the study. However, the residual determines the accrual quality, the larger the residuals, the lower the quality of accruals vice versa. Heteroscedasticity was estimated and regression was run using Stata 10. Various tests were conducted, ranging from multicolinearity test, normality test. The choice of this is based on the fact that both the technique and tool are more informative (i.e. more variability, less collinearity, more degrees of freedom), as estimates are more efficient under it. Also they allow the study of individual dynamics. While this technique and tool gives information on the time-ordering of events, they also allow for control of individual unobserved heterogeneity.

\subsection{Model Specification}

The model that examines the hypotheses of the study is presented as follows:

$$
\mathrm{EQ}_{\mathrm{it}}=\beta \mathrm{o}_{\mathrm{it}}+\beta_{1} \mathrm{NON} \mathrm{EX}_{\mathrm{it}}+\beta_{2} \mathrm{WD}_{\mathrm{it}}+\beta_{3} \mathrm{FRD}_{\mathrm{it}}+\beta_{4} \mathrm{BSZ}_{\mathrm{it}}+\beta_{5} \mathrm{ROA}_{\mathrm{it}}+\mu_{\mathrm{it}}
$$


Where:

$\mathrm{EQ}=$ Earnings Quality

NON EX = Non Executive Directors

$\mathrm{WD}=$ Women Directors

$\mathrm{FRD}=$ Foreign Directors

BSZ $=$ Board Size

ROA $=$ Profitability

$\beta_{1-} \beta_{6}=$ Coefficient of explanatory variables

$\beta_{\mathrm{o}}=$ Constant or Intercept

$\mu=$ Error Term

\subsection{Variable Measurement}

Table 3.2

\begin{tabular}{|c|c|c|}
\hline S/No & Variables & Measurement \\
\hline 1 & $\begin{array}{l}\text { Earnings } \\
\text { Quality }\end{array}$ & $\begin{array}{l}\text { To measure the earnings quality of firms under study in the } \\
\text { sample, the Discretionary Accounting Accruals (DAA) used by } \\
\text { management was chosen. Based on this view, the higher the level of } \\
\text { DAA, the greater the distance between the economic performance and } \\
\text { results shown in the financial statements. Thus, the higher the earning } \\
\text { quality the higher the quality of the financial information presented by } \\
\text { the firm. } \\
\text { Accounting information quality is an elusive concept in the } \\
\text { accounting literature. Consequently, there is little agreement among } \\
\text { researchers about how best to measure accounting information quality } \\
\text { (Dechow et al, 1995). The scarcity of readily available data in an } \\
\text { international setting further complicates this issue. As a result, this } \\
\text { study relies on the accruals quality of the Nigerian quoted } \\
\text { conglomerate firms using Francis et al. (2005) model. This is because } \\
\text { conglomerate firms are curved out of manufacturing firms. } \\
\text { Thus, residuals of DAAit }=\beta 0+\beta 1 \text { CFOit }-1+\beta 2 \text { CFOit }+\beta 3 \text { CFOit } \\
+1+\beta 4 \triangle R E V i t+\beta 5 P P E i t+\varepsilon \text {. }\end{array}$ \\
\hline 2 & $\begin{array}{l}\text { Non } \\
\text { Executive } \\
\text { Directors }\end{array}$ & $\begin{array}{l}\text { Proportion of non executive directors to total directors on the Board } \\
\text { (Fodio } \text { et al. 2013). }\end{array}$ \\
\hline 3 & $\begin{array}{l}\text { Women } \\
\text { Directors }\end{array}$ & $\begin{array}{l}\text { Proportion of women directors to total directors on the Board (Bart \& } \\
\text { Mcqueen, 2013). }\end{array}$ \\
\hline 4 & $\begin{array}{l}\text { Foreign } \\
\text { Directors }\end{array}$ & $\begin{array}{l}\text { Proportion of foreign directors to total directors on the Board (An, } \\
\text { 2009). }\end{array}$ \\
\hline 5 & Board Size & tal. 2013). \\
\hline
\end{tabular}

\section{Results, Analysis and Discussions}

This chapter analyses the trend of the variables using descriptive statistics. It is followed by the results of normality test using S-wilk test, correlation matrix and robustness test of the study. In addition the results of the model estimations and the inferences drawn from the tests of the hypotheses are also given and finally, findings are discussed and policy implications are analyzed.

\subsection{Descriptive Statistics}

The descriptive statistics is presented in Table 4.1 where minimum, maximum, mean, standard deviation, skewness and kurtosis of the data for the variables used in the study are captured. 
Table 4.1: Descriptive Statistics

\begin{tabular}{|l|l|l|l|l|l|l|}
\hline Variable & Mean & Minimum & Maximum & Std. Dev & Kurtosis & Skewness \\
\hline EQ & 1.824932 & 0.006421 & 4.40311 & 1.151006 & 2.155053 & 0.2072871 \\
\hline NON-EX & 0.6908865 & 0.4285714 & 0.90000 & 0.1055205 & 2.471714 & -0.067309 \\
\hline WD & 0.2187096 & 0.833333 & 0.375 & 0.688282 & 2.600192 & 0.3274394 \\
\hline FRD & 0.2515476 & 0.706893 & 0.7272727 & 0.2576363 & 2.407479 & 1.168257 \\
\hline BSZ & 10 & 0.6 & 13 & 2.016878 & 1.8875 & -0.4125 \\
\hline ROA & 0.1830383 & 0.0070531 & 2.330218 & 0.3196483 & 35.49299 & 5.374617 \\
\hline
\end{tabular}

SOURCE: STATA OUTPUT 2016

Table 4.1 above shows that the measure of earnings quality (EQ) of the conglomerate firm sector has a mean value of 1.824932 with standard deviation of 1.151006 , and minimum and maximum values of 0.006421 and 4.40311 respectively. This implies that the average earnings quality in conglomerate firms is 1.824932 to 4.40311 , and the deviation from both sides of the mean is 1.151006 . This suggests that the dispersion of the data from the mean is not too wide because the standard deviation is a little bit high. The peak of the data is indicated by the kurtosis value of 2.155053, suggesting that most of the values are higher than mean, hence the data did not meet a normal distribution assumption. The coefficient of Skewness of 0.2072871 implies that the data is positively skewed (that is, most of the data are on the right side of the normal curve); thus, the data does not meet the symmetrical distribution assumption (Kothari, 2004).

Again the table indicates an average non-executive directors' (Non-Ex) of 0.6908865 with standard deviation of 0.1055205 , the minimum and maximum values is 0.4285714 and 0.90000 respectively. This implies that on average non-ex in conglomerate firms is 0.690885 and the data deviate from both sides of the mean by 0.1055205 . This suggests a wide dispersion of the data from the mean because the standard deviation is close to the mean value. The peak of the data is indicated by the kurtosis value of 2.471714 , suggesting that most of the values are higher than mean, and the data did not meet a normal distribution assumption. The coefficient of Skewness of -0.067309 implies that the data is negatively skewed (that is, most of the data are on the left side of the normal curve), thus, the data does not meet the symmetrical distribution assumption (Kothari, 2004).

The Table also indicates average women directors (WD) of 0.2187096 with standard deviation of 0.688282 , the minimum and maximum values of 0.083333 and 0.375 respectively. The standard deviation from both sides of the mean is 0.688282 . This also suggests a wide dispersion of the data from the mean because the standard deviation is close to the mean value. The peak of the WD data is indicated by the kurtosis value of 2.600192, suggesting that most of the values are higher than mean, and the data did not meet a normal distribution assumption. The coefficient of Skewness of 0.3274394 implies that the data is positively skewed (that is, most of the data are on the right side of the normal curve), implying that the data does not meet the symmetrical distribution assumption (Kothari, 2004).

Moreover, Table 4.1 shows average foreign directors (FRD) of 0.2515476 with standard deviation of 0.2576363 , the minimum and maximum values are 0.706893 and 0.7272727 respectively. The deviation from both sides of the mean is 0.2576363 . This suggests a wide dispersion of the data from the mean because the standard deviation is close to the mean value. The kurtosis value of 2.407479 suggest that most of the values are higher than mean, and the data did not meet a normal distribution assumption; the Skewness value of 1.168257 implies that the data is positively skewed (that is, most of the data are on the right side of the normal curve), implying that the data does not meet the symmetrical distribution assumption (Kothari, 2004).

Similarly, the results in Table 4.1 indicate that board size (BSZ) has a mean value of 10 with standard deviation of 2.016878, and minimum and maximum values of 6 and 13 respectively. The deviation from both sides of the mean is 2.01687. This also suggests a wide dispersion of the data from the mean because the mean value is high compared to the standard deviation value. The peak of the BSZ data is indicated by the kurtosis value of 1.8875 , suggesting that most of the values are higher than mean, and the data did not meet a normal distribution 
assumption. The coefficient of Skewness of -0.4125 implies that the data is negatively skewed (that is, most of the data are on the left side of the normal curve), implying that the data does not meet the symmetrical distribution assumption (Kothari, 2004).

Lastly, Table 4.1 indicates an average return on asset (ROA) of 0.1830383 with standard deviation of 0.319483 , and minimum and maximum values of 0.0070531 and 2.330218 respectively. The deviation from the mean is 0.319483 . This suggests a wide dispersion of the data from the mean because the standard deviation is close to the mean. The peak of the ROA data is indicated by the kurtosis value of 35.49299, suggesting that most of the values are higher than mean, and the data did not meet a normal distribution assumption. The coefficient of Skewness of 5.374617 implies that the data is positively skewed (that is, most of the data are on the right side of the normal curve), implying that the data does not meet the symmetrical distribution assumption (Kothari, 2004).

The analysis of the descriptive statistics of the variables of the study shows the nature and extent of dispersion of the data, which strongly suggested that the data did not follow the normal curve as indicated by the high values of standard deviations, skewness and kurtosis. Therefore, the test of normal data is conducted and the results are presented in table 4.2 as follows:

Table 4.2: Normal Data Test

\begin{tabular}{|l|l|l|l|l|}
\hline Variables & W & V & Z & Probability \\
\hline EQ & 0.96414 & 1.949 & 1.439 & 0.07513 \\
\hline NON-EX & 0.98588 & 0.768 & -0.570 & 0.71576 \\
\hline WD & 0.97907 & 1.138 & 0.278 & 0.39049 \\
\hline FRD & 0.67183 & 17.839 & 6.211 & 0.0000 \\
\hline BSZ & 0.95014 & 2.710 & 2.249 & 0.01581 \\
\hline ROA & 0.42415 & 31.301 & 7.423 & 0.0000 \\
\hline
\end{tabular}

SOURCE: STATA OUTPUT 2016

Under Shapiro-Wilk (W) test for normal data, null hypothesis principle is used to check a variable that came from a normally distributed population. The null hypothesis of the test is that, the data is normally distributed (Gujarati, 2004). Table 4.2 indicates that data from foreign directors, board size and return on assets did not follow the normal distribution, because the P-values of the test statistics (Z-Values) are statistically significant at $1 \%$ level of significance. Thus, the null hypothesis (that, the data is normally distributed) is rejected at $1 \%$ significance levels. This implied that the model of the study may require a more generalized estimators. However the fact that data from foreign directors, board size and return on assets are not normally distributed will not affect the validity of the statistical inferences drawn (Guasian theorem, 1929; Shao \& Gaws, 2003).

Therefore, having analyzed the descriptive statistics and normality of the data, the correlation matrix is presented and discussed in the following section.

\subsection{Correlation Matrix}

The correlation matrix is presented in table 4.3 where the relationship of the independent variable and the dependent variable is analysed and also between independent variables and themselves.

Table 4.3: Correlation Matrix

\begin{tabular}{|l|l|l|l|l|l|l|}
\hline Variables & EQ & NON-EX & WD & FRD & BSZ & ROA \\
\hline FRQ & 1.0000 & & & & & \\
\hline NON-EX & -0.4235 & 1.0000 & & & & \\
\hline WD & 0.0728 & -0.2512 & 1.0000 & & & \\
\hline FRD & -0.6319 & 0.5821 & -0.4373 & 1.0000 & & \\
\hline BSZ & -0.2500 & 0.4094 & 0.3956 & 0.2490 & 1.0000 & \\
\hline ROA & 0.2339 & -0.1409 & 0.7055 & -0.1795 & 0.5463 & 1.0000 \\
\hline
\end{tabular}

SOURCE: STATA OUTPUT 2016 
The results in Table 4.3 show the degree of association between earnings quality (EQ) and all pairs of independent variables individually as well as between themselves and cumulatively with the dependent variable (EQ) of the study in the conglomerate firms. The table presents a negative relation between earnings quality (EQ) and non-executive (Non Ex) directors from the correlation coefficient of -0.4235 . This relationship implies that as the proportion of NonEx increases the EQ of the conglomerate firms will decrease. Table 4.3.1 shows that there is positive association between EQ of the conglomerate firms and women directors (WD) of the firms, from the correlation coefficient of 0.0728 which is statistically significant at all levels of significance. This relationship implies that as the proportion of women directors of the firms increases the EQ will also improve significantly and statistically.

Moreover, the table indicates a negative correlation between EQ and foreign directors (FRD) from the correlation coefficient of -0.6319 which is statistically significant at all levels of significance. This relationship implies that as the foreign director increases the EQ of the firms in Nigeria will decrease statistically and significantly. The table also indicates a negative relationship between EQ and board size (BSZ) from the correlation coefficient of -0.2500 . Table 4.3.1 also shows an insignificant positive relationship between EQ and return on assets (ROA) which is a control variable in this study from the correlation coefficient of 0.2339 which is statistically insignificant at any level of significance.

The analysis of the relationships among the independent variables and themselves indicated mostly positive and insignificant. However, to conclude the relation and the impact of the dependent variable (EQ) and all the pairs of independent variables (non-executive directors, women directors, foreign directors and board size) of Nigerian conglomerate firms the estimators from the regression of the model of the study is analyzed in the following section.

\subsection{Regression Results}

The analysis of the regression results of the models of the study is presented and discussed in this section. The results are presented in table 4.4 .

Table 4.4: Robust OLS Regression Results

\begin{tabular}{|l|l|l|l|l|l|}
\hline Variables & Coefficients & t-values & p-values & VIF & $\begin{array}{l}\text { Tolerance } \\
\text { Values }\end{array}$ \\
\hline NON-EX & -0.2911285 & -16.86 & 0.000 & 2.67 & 0.373813 \\
\hline WD & -0.637406 & -5.50 & 0.000 & 2.56 & 0.390034 \\
\hline FRD & 0.0061683 & 0.28 & 0.779 & 2.37 & 0.422414 \\
\hline BSZ & -0.0053594 & -1.10 & 0.271 & 1.94 & 0.514370 \\
\hline ROA & 0.1051741 & 3.67 & 0.000 & 1.93 & 0.518640 \\
\hline Mean VIF & & & & & $\mathbf{2 . 2 9}$ \\
\hline Intercept & 1.310839 & 9.85 & 0.000 & & \\
\hline R $^{2}$ & & & $\mathbf{0 . 6 3}$ & & \\
\hline F-Statistics & & & $\mathbf{3 5 3 . 6 6}$ & & \\
\hline F-Sig & & & $\mathbf{0 . 0 0 0 0}$ & & \\
\hline
\end{tabular}

\section{SOURCE: STATA OUTPUT 2016}

The cumulative $\mathrm{R}^{2}(0.63)$ which is the multiple coefficient of determination gives the proportion or percentage of the total variation in the dependent variable as explained by the independent variable jointly. Hence, it signifies $63 \%$ of total variation in earnings quality of Nigerian conglomerate firms is caused by the collective effort of Non-executive directors, women directors, foreign directors and board size. This result further indicates that the model is fit, variables properly selected, combined and used in the study. This is statistically supported by the F-Sig (0.0000). The tolerance values and the variance inflation factor are two good measures of assessing multicolinearity between the independent variables in a study. The result shows that variance inflation factor were consistently smaller than ten (10) indicating complete absence of multicolinearity. This shows the suitability of the study model been fit with the four independent variables. Also, the tolerance values were consistently smaller than 
1.00 , therefore extend the fact that there is complete absence of multicolinearity between the independent variables.

\subsubsection{Non-Executive Directors and Earnings Quality}

The regression result in table 4.4 revealed that non executive directors as measured by the proportion of non-executive directors on the board has a t value of -16.86 , coefficient value of -0.2911285 and is significant at $1 \%$ level of significance. This signifies that Non-Executive directors' is negatively, strongly and statistically related with earnings quality of listed conglomerate firms in Nigeria. This implies that for every 1 increase in the number of Nonexecutive directors' on the board the earnings quality will improve by $29 \%$. This is not surprising considering the fact that non executive directors are free from managerial influence and capable of monitoring them efficiently which improves the quality of financial information conveyed to the users of financial statement of the Nigerian conglomerate firms. In addition, this study finds that the increase in the number of non executive directors in the board reduces unethical accounting which has a positive role in determining the quality of earnings of Nigerian conglomerate firms. This may be as a result of outside members do not play a direct role in the management of the company; their existence may provide an effective monitoring tool to the board and thus reduces earnings management by managers which produces higher quality of financial reports.

Thus, the finding is line with our expectations. Therefore, in line with the result the null hypothesis $1, \mathrm{H}_{\mathrm{o}}$, is rejected. This finding is in line with Fama Hwang \& Kim (2009), Hashim \& Devi (2010) and Muravyev et al (2016) and contradict the findings of Smith (2015), Hashim \& Devi (2008) and Adebimpe \& Peace (2011).

\subsubsection{Women Directors and Earnings Quality}

The study's expectation is that firms with women as directors have stronger desires and are more likely to protect manipulation of earnings because they are more likely to possess skills such as legal, human resources, communications rather than line functions of operations, marketing compared to men. Also, women are more likely to hold valuable, unique and rare information because they have been excluded from the path of directorship. The results of the regression in table 5 has confirmed our expectation in respect of women directors and earnings quality as it shows that women directors is negatively associated with EQ with a $t$ value of -5.50 , a coefficient of -0.637406 and significant at $1 \%$. This implies that the larger the number of women directors in Nigerian conglomerate firms, the more quality of earnings in their financial statements. This also means for every 1 increase in women directors the quality of the earnings will improve by $64 \%$. This result may be due the quest for women directorship is mostly based on objectivity and not for mare reflection of the structure of society, appropriate representation of gender and internal or external calls for diversity eg issue of gender equality.

The finding is not surprising both on sign and effect. Thus, this provides an evidence of rejecting the second hypothesis of the study. Thus, for Hypothesis $2, \mathrm{H}_{\mathrm{o}}$ is rejected. This is in line with the findings of Singh \& Vinicombe (2004), Hillman et al (2002) and Zelechowski \& Bilimoria (2004) and contradicts the findings of Ding \& Charoenwong (2004), Farrel \& Hersch (2005) and Al-Hayale \& Lan (2004).

\subsubsection{Foreign Directors and Earnings quality}

In addition, the result of foreign directors in determining the strength or weakness of the earnings quality as shown in table 4.5 reveals a t-value of 0.28 and a beta value of 0.0061683 with a p-value of 0.779 . This signifies that foreign directors do not have any significant effect on earning quality of Nigerian listed conglomerate firms. This result is inconsistent with our priory expectations that the presence foreign director on the board will check the opportunistic tendencies of internal directors to manipulate earnings as a result of their expertise and experience to guide the management in steering the affairs of the firm well in order to achieve desired end and hence improve the quality of earnings of Nigerian conglomerate firms.

Therefore this finding provides evidence of failing to reject hypothesis three of the study. Thus, for Hypothesis $3, \mathrm{H}_{\mathrm{o}}$ is failed to be rejected. This finding supports the findings of Olowookere \& Adebiye (2016), Grinbblatt \& Keloharju (2000) and Hooghiemstra et al (2016) 
and contradict the finding of Kang \& Stulz (1997), Alzoubi (2016), Khanna \& Palepu (2000) and Sachs \& Warner(1995).

\subsubsection{Board Size and Earnings quality}

The regression result in table 4.4 reveals that board size has a t-value of -1.10 with regression coefficient of 0.0053594 which is statistically insignificant at all level of significant. This implies that board size does not have any significant effect on earnings quality of Nigerian conglomerate firms. However, the result is surprising because the prior expectation is that large board size will improve the earnings quality because larger boards are expected to commit more time and effort while smaller board will commit less time and effort to oversee management. Similarly, in reality, board monitoring tends to be positively associated with larger board due to their ability to distribute the work load over a greater number of observations (Klein, 2002). However, this result may be as a result of larger boards sometimes exhibited poorer coordination and communication between members (Palenzuela \& Iturriaga, 2000).

However, this finding was found to be contrary with our priory expectations. Therefore, this result forms the basis of failing to reject hypothesis four. Thus, for Hypothesis $4, \mathrm{H}_{\mathrm{o}}$ is failed to be rejected. The outcome of this study is in line with the findings of Abdulrahman \& Ali (2006), Kao \& Chen (2004) and Alotaibi \& Hussaine (2016) and disagree with the findings of Monk \& Minow (2004), Bedard et al (2004), Yu (2008) and Ramachandran et al (2015).

\section{Conclusion and Recommendations}

Based on the results and findings, First, the study has provided both empirical as well as statistical evidence on the utility of four independent variables that constitute board characteristics ie non executive directors, women directors, foreign directors and board size in explaining and predicting earnings quality of the sample firms. The study revealed that non executive directors play a positive role of monitoring management to reduce their opportunistic behavior in managing earnings. Therefore, the presence of higher proportion of non executive directors on corporate board is likely to enhance the earnings quality reported by the firms. Thus, efficient monitoring from non-executive directors that are free from managerial influence is capable of improving the quality of financial information conveyed to the user of financial statement. Similarly, the study revealed that a negative association exists between women directors and earnings quality of Nigerian listed conglomerate firms. This suggests that women directors play a positive role in monitoring management to reduce their behavior in managing earnings opportunistically. Therefore, higher proportion of women members on corporate board of Nigerian listed conglomerate firms is likely to improve the quality reported earnings by the firms. And finally, the study found that the insignificant impact of foreign directors and board size on earnings quality is an indication that firms with a higher numbers of foreign directors and large board size may not necessarily influence the quality of the earnings of Nigerian conglomerate firms. Therefore, the study concluded that foreign directors and board size have not impacted on earning quality of listed conglomerates firms within the study period. On the whole, the study concludes that board characteristics has significantly improve the earnings quality of the listed conglomerate firms in Nigeria, except for foreign directors and board size that were found to be insignificant.

In line with the findings and conclusions of the study, it is recommended that the securities and exchange commission should ensure that company's board in Nigerian conglomerate firms should be composed by the shareholders in such a way that the representation of nonexecutive directors is more as it was found that it discourages earnings management, hence improve the quality of information conveyed to users of financial statement. Also companies most strictly comply with the provision of part B 4.3 of the Code of Corporate Governance which provides that majority of board members should be non executive directors with at least one independent director to forestall any tendency of conniving with management for personal gains. Similarly, the study recommends that, governments, policy makers (SEC and Corporate Affairs Commission) and other stakeholders should initialized a process of encouraging the presence of more women directors on the board of Nigerian conglomerate firms without compromising objectivity and value addition or mere quest for women directorship for reflection of the structure of society. 


\section{References}

Abdul Rahman, R., \& Ali, F. H. M. (2006). Board, Audit Committee, Culture And Earnings Management: Malaysian Evidence. Managerial Auditing Journal, 21(7), 783-804.

Abdullah, S. N. \& Mohammed, N. (2004). Accrual management and the independence of the board of directors and audit committees. IIUM Journal of Economics and Management, $12 \quad(1), 49-80$.

Abdulrahman, R. \& Mohamed A., (2006), Board, audit committee, culture and earnings management: Malaysian evidence, Managerial Auditing Journal, 21(7), 783-804.

Adelopo, I. A. (2010). Voluntary Disclosure Practices Among Listed Firms in Nigeria Available at SSRN: http://ssrn.com/abstract

Afande, F. O. (2015). Change Management Practices: A Case of Introduction of Integrated Payroll and Personnel Database System at the Ministry of Medical Services, Nairobi Kenya, European Journal of Small Business and Management.

Agoraki, M.-E., Delis, M. D. \& Staikouras, P. (2009). The Effect of Board Size and Composition on Bank Efficiency. Munich Personal RePEc Archive Paper No. 18548.

Agrawal, A. \& Knoeber, C. R. (1996). Firm performance and mechanisms to control agency problems between managers and shareholders. Journal of financial and quantitative analysis, 31(03), 377-397.

Ahmad, A. C. \& Mansor, N. (2009). Board Independence, Ownership Structure, Audit Quality and Income Smoothing Activities: A Study on Malaysian Market. Journal of Modern Accounting and Auditing.

Akpan, E. O. \& Amran, N. A. (2014). Board Characteristics and Company Performance: Evidence from Nigeria, Jounal of accounting and Finance 2(3), 81-89

Al-Hayale, T., \& Lan, G. (2004). The Effect of Gender on the Ethical Attitudes of Jordanian Managers and Auditors toward Earning Management. Working paper, Presented at the Annual Meeting of the American Accounting Association in Orlando.

Alotaibi, K. O. \& Hussainey, K. (2016). Determinants of CSR disclosure quantity and quality: Evidence from non-financial listed firms in Saudi Arabia. International Journal of Disclosure and Governance.

Alzoubi, E. S. S. (2016) Ownership structure and earnings management: evidence from Jordan, International Journal of Accounting \& Information Management, 24(2).

An, Y. H. (2009). The effect of corporate governance and earnings quality: Evidence from Korea's corporate governance reform. Thesis (P.Hd.)

Adebimpe, D. U. \& Peace, O. (2011). Corporate governance, company attributes and voluntary disclosures: A study of Nigerian listed companies. CHIEF

PATRON CHIEF PATRON.

Bart, C. \& Mcqueen G. (2013). Why women make better directors. Int. Journal of Business Governance and Ethics, 8(1).

Bedard, J., Chtourou, S.M., \& Courteau, L. (2004). The Effect of Audit Committee Expertise, Independenc eand Activity on Aggressive Earnings Management. Auditing: $A$

Journal of Practice \& Theory, 23, 55-79.

Belkhir, M. (2009). Board Structure, Ownership Structure and Firm Performance: Evidence

from Banking. Journal of Applied Financial Economics, 19, 1581-1593.

Belski, W. H, Beams, J. D. \& Brozovsky, J. A. (2008) "Ethical judgments in Accounting: An Examination on the Ethics of Managed Earnings," Journal of Global Business Issues, 2(2).

Bilimoria, D., \& Wheeler, J. V. (2004). Women Corporate Directors: Current Research and Future Directions. Women in Management: Current Research Issues, II, 138 - 163. London:

Boone, A. L., Field, L. C., Karpoff, J. M. \& Raheja, C. G. (2007). The determinants of corporate board size and composition: an empirical analysis. Journal of

Financial Economics, 85, 66-101.

Borgia, F. (2005). Corporate governance and transparency, the role of disclosure. How to prevent new financial scandals and crime, Washington D.C. pdf.

Burke R. J., \& Mattis, M. C. (eds.) (2000). Women Corporate Boards of Directors. In R.J. Burke and M. C. Mattis, (eds.). Women on Corporate Boards of Directors: International Challenges and Opportunities, 3 - 10. Dordrecht: Kluwer Academic Publishers. 
Burke, R. J. (1997). Women on corporate boards of directors: A needed resource.

Burke, R. J. (2000). Women on Corporate Boards of Directors: Understanding the context. In

R. J. Burke and M. C. Mattis, (eds.). Women on Corporate Boards of Directors:

International Challenges and Opportunities, pp. 179 - 196. Dordrecht: Kluwer

Academic Publishers.

Chtourou, S. M., Bedard, J. \& Courteau. L. (2001). Corporate governance and earnings management. Working paper, University of Laval.

Clikeman, P. M., Geiger, M. A., \& O Connell, B. T. (2001). Student Perceptions of Earnings Management: The Effects of National Origin and Gender. Teaching Business Ethics, 5, 389-410.

Cornett, M. M., Marcus, A. J., Saunders, A. \& Tehranian, H. (2007). The impact of institutional ownership on corporate operating performance. Journal of Banking

$\& \quad$ Finance, 31(6), 1771-1794.
Daily, C. M., Certo, S. T., \& Dalton, D. R. (1999). A Decade of Corporate Women: Some Progress in the Boardroom, None in the Executive Suite. Strategic Management Journal, 20(1), 93-99.

Daily, C. M., Certo, S. T., \& Dalton, D. R. (2000). The Future of Corporate Women: Progress toward the Executive Suite and the Boardroom? In R. J. Burke and M.C. Mattis, (eds.). Women on Corporate Boards of Directors: International Challenges and Opportunities, 11- 23. Dordrecht: Kluwer Academic Publishers.

Dahlquist, M. \& Robertson, G. (2001) Direct foreign ownership, istitutional investors, and firm characteristics. Journal of Financial Economics, 59: 413-440.

Dalhat, M. H. (2014), Corporate Governance Mechanism and earnings Quality of Listed Manufacturing Company in Nigeria. Thesis (M.Sc.)

Dechow, P., Sloan, R. \& Sweeney, A. (1995). Causes and consequences of earnings manipulation: An analysis of firms subject to enforcement actions by the SEC. Contemporary Accounting Research, 13(1). www.emerdinsight.com

Dimitropoulos, P. A. \& Asteriou, D. (2010). The Effect of board composition on the informativeness and quality of annual earnings: Empirical evidence from Greece. Research in International Business and Finance, 24, 190-205.

Ding, D. K., \& Charoenwong, C. (2004). Women on Board: Is it Boon or Bane? FMA European Conference, Financial Management Association. June $2-5$,

Zurich, Switzerland.

Djumena, E. (2011). Bisnis Keuangan. Retrieved April 13, 2016, from Kompas.com: http://www.kompas.com

Donaldson, L., \& Davis, J. H. (1991). Stewardship theory or agency theory: CEO governance and shareholder returns. Australian Journal of management, 16(1), 49-64.

Fama, E. \& Jensen, M. (1983). Separation of ownership and control, Journal of Law and Economics, 26(2), 301-25

Feng, L. \& Seasholes, M. S. (2008). Individual investors and gender similarities in an emerging stock market. Pacific-Basin Finance Journal, 16(1), 44-60.

Farrell, K. A., \& Hersch, P. L. (2005). Additions to Corporate Boards: The Effect of Gender. Journal of Corporate Finance, 11(1-2), 85-106.

Fodio M. I., Ibikunle J. \& Chiedu V. (2013). Corporate Governance Mechanism and Reported Earnings Quality in Nigerian Insurance Firm. International Journal

of Finance and Accounting, 2(5), 279-286.

Fondas, N., \& Sassalos, S. (2000). A Different Voice in the Boardroom: How the Presence of Women Directors Affects Board Influence over Management. Global Focus, 12(2), 13- 22.

Francis, J., LaFond, R., Olsson, P. \& Schipper, K. (2005). The market pricing of accruals quality. Journal of accounting and economics, 39(2), 295-327.

Frick, B. \& Bermig, A. (2010). Board Size, Board Composition and Firm Performance: Empirical Evidence from Germany. Working Paper Series June, http://www.ssrn.com.

Grinblatt, M. \& Keloharju, M. (2000). The investment behaviour and performance of various investor types: a study of Finland's unique data set. Journal of Financial Economics 55, 43-67.

Hannifa, R.M. \& Cooke, T.E. (2002). Culture, Corporate Governance and disclosure in Malaysian corporations. ABACUS, 38(3), 317-349. 
Hashim, H. A. \& Devi, S. S. (2008). Board composition, ownership structure and earnings quality: Malaysian evidence. Asian journal of Business and Accounting. 1 (1), 27-46.

Hashim, H. A. \& Devi, S. S. (2010). Corporate governance, ownership structure and earnings quality: Malaysian evidence. Working Paper.

Hidayat, B. A., Sinoeraya, E. K. \& Widyaningsih, R. (2016). The Effect of Reported Comprehensive Income, Firm Size, Profitability and Leverage on Income

Smoothing: A Study on Companies of Consumer Goods in Manufacturing Sector

Listed in Indonesia Stock Exchange. Social Science Research Network

Hillman, A. J., Canella Jr, A. A., \& Harris, I. C. (2002). Women and Racial Minorities in Boardroom: How Do Directors Differ? Journal of Management, 28(6), 747-

763.

Hooghiemstra, R., Hermes, N., Oxelheim, L. \& Randoy, T. (2016). The Impact of Board Internationalization on Earnings Management. Social Science Research Network,

IFN working paper 1096

Huse, M., \& Solberg, A. G. (2006). Gender Related Boardroom Dynamics: How Scandinavian Women Make and Can Make Contributions on Corporate Boards. Women in Management Review, 21(2), 113-130

Hwang \& Kim (2009). It Pays To Have Friends, Journal of Financial Economics 93, 138-158.

Ingley, C. B., \& Van der Walt, N. T. (2001). The Strategic Board: The Changing Role of Directors in Developing and Maintaining Corporate Capability. Corporate Governance: An International Review, 9(3), 174-185.

Jaggi, B., \& Leung, S. (2007). Impact of family dominance on monitoring of earnings management by audit committees: Evidence from Hong Kong. Journal of International Accounting, Auditing and Taxation, 16(1), 27-50.

Jamali, D., Safieddine, A., \& Daouk, M. (2007). Corporate Governance and Women: An Empirical Study of Top and Middle Women Managers in Labanese Banking

Sector. Corporate Governance, 7(5), 574-585.

Jensen, M.C. \& Meckling, W.H. (1976). Theory of the Firm: Managerial behavior, agency costs and ownership structure. Journal of Financial Economics, 4, 305-360.

Kamaruzaman, A. J., Mazlifa M.D., \& Maisarah A. R (2009). The Association between Firm Characteristics and Financial Statements Transparency: the case of Egypt, International Journal of Accounting, 18 (2), 211-223.

Kang H., Cheng, M. \& Gray, S.J. (2007). Corporate Governance and Board Composition: Diversity and Independence of Australian Boards. Corporate Governance: An International Review, 15(2).

Kang, J.K. \& Stulz, R.M. (1997). Why is there a home bias? An analysis of foreign portfolio equity ownership in Japan. Journal of Financial Economics 46, 328.

Kao, L., \& Chen, A. (2004). The Effects of Board Characteristics on Earnings Management. Corporate Ownership \& Control, 1(3), 96-107.

Keasey, K., Thompson, S., \& Wright, M. (eds). (1997). Corporate Governance: Economic, Management, and Financial Issues. Oxford: Oxford University Press.

Khanna, T., Palepu, K.G. (2000). Is group affiliation profitable in emerging markets: An analysis of diversified Indian business groups. Journal of Finance 55, 867-

891.

Kim, K. A., Nofsinger, J. R. \& Mohr, D. J. (2010). Corporate Governance (3rd edition). New Jersey: Pearson Education, Inc.

Klein, A. (2002). Audit Committee, Board of Director Characteristics, and Earnings Management. Journal Accounting and Economics, 33, 375-450.

Krishnan, G.V., \& Parsons, L.M. (2008). Getting to the Bottom Line: An Exploration of Gender and Earnings Quality. Journal of Business Ethics, 78, 65-76.

Kyereboah-Coleman, A. \& Biekpe, N. (2006). The Relationship Between Board Size, Board Composition, CEO Duality and Firm Performance: Experience from Ghana. Corporate Ownership and Control Journal, 4(2), 114-112.

Letendre, L. (2004). The Dynamics of the Boardroom. Academy of Management Executive, 18(1), 101-104.

Menozzi, A., Urtiaga, M. G. and Vannoni, D. (2010). Board Composition, Political Connections and Performance in State-Owned Enterprises. Carlo Alberto Notebooks No.185. 
Park, Y. N. \& Shinn H. H. (2004). Board composition and earnings management in Canada. Journal of corporate finance, 10(8), 431-457.

Muravyev, A. Talavera, O. \& Weir, C. (2016). Performance effects of appointing other firms' executive directors to corporate boards: an analysis of UK firm. Review of Quantitative Finance, 46(1), 25-45

Olowookere, J. K. \& Adebiye, W. K. (2016). Ownership structure and quality of financial reporting: Evidence from Nigerian deposit money banks. International Journal of Economics, Commerce and Management, iv(1).

Pearce II, J. A., \& Zahra, S. A. (1991). The Relative Power of the CEOs and Boards of Directors: Associations with Corporate Performance. Strategic Management Journal, 12(2), 135- 153.

Qin, L. \& Liwen, T. (2007). An Empirical Analysis of the Relation Between Board Independence and Earnings Management. Conference on Enterprise Engineering and Management Innovation 2007.

Ramachandian, J., Ngete, Z. A., Subramanian, R. \& Sambasivan, M. (2015). Does corporate governance influence earnings management?: Evidence from Singapore. The Journal of Developing areas, 49(3), 263-274

Sanda, A. Mikailu, A. S. \& Garba, T. (2005), Corporate Governance Mechanism and firm financial performance in Nigeria. A paper presented at Africa Economic Research Consortium, Nairobi Kenya, and March 2005. 1-37

Schipper, K. \& Vincent, L. (2003). Earnings Quality. Accounting Horizon, Annual, 67-111.

Singh, V., \& Vinnicombe, S. (2004). Why so Few Women Directors in Top UK Boardrooms? Evidence and Theoretical Explanations. Corporate Governance: An International Review, 12(4), 479-488.

Smith, A. (2015). The quality of reported earnings and the monitoring role of the board: Evidence from small and medium companies. South African Business

Review, 19(2)

Smith, N., Smith, V., \& Verner, M. (2006). Do Women in Top Management Affect Firm Performance? A Panel Study of 2,500 Danish Firms. International Journal of Productivity and Performance Management, 55(5), 569-593.

Srinidhi, B., Gul, F. A. \& Tsui, J. (2011). Female Directors and Earnings Quality. Contemporary Accounting Research, 28(5), 1610-1644.

Terjesen, S., Couto, E. B. \& Fransisco, P. M. (2015). The Effect of Board Independence on the Earnings Quality: Evidence from Portuguese Listed Companies. Journal of Management and Governance, 1-37

Uadiale, O. M. (2010). The Impact of Board Structure on Corporate Financial Performance in Nigeria. International Journal of Business and Management, 5(10), 155-166

Velte, P. (2016). Women on management board and ESG performance. Journal of Global Responsibility, 7(1)

Xie, B., Davidson, W., \& DaDalt, P. (2003). Earnings Management and Corporate Governance: The Roles of the Board and the Audit Committee. Journal of Corporate Finance, 9(3), 295-317.

Yu, F. (2008). Corporate Governance and Earnings Management. Journal of Financial Economics, 88, 245-271.

Zelechowski. D. D., \& Bilimoria, D. (2004). Characteristics of Women and Men Corporate Inside Directors in the US. Corporate Governance: An International Review, 12(3), 337- 342. 


\section{RESULTS}

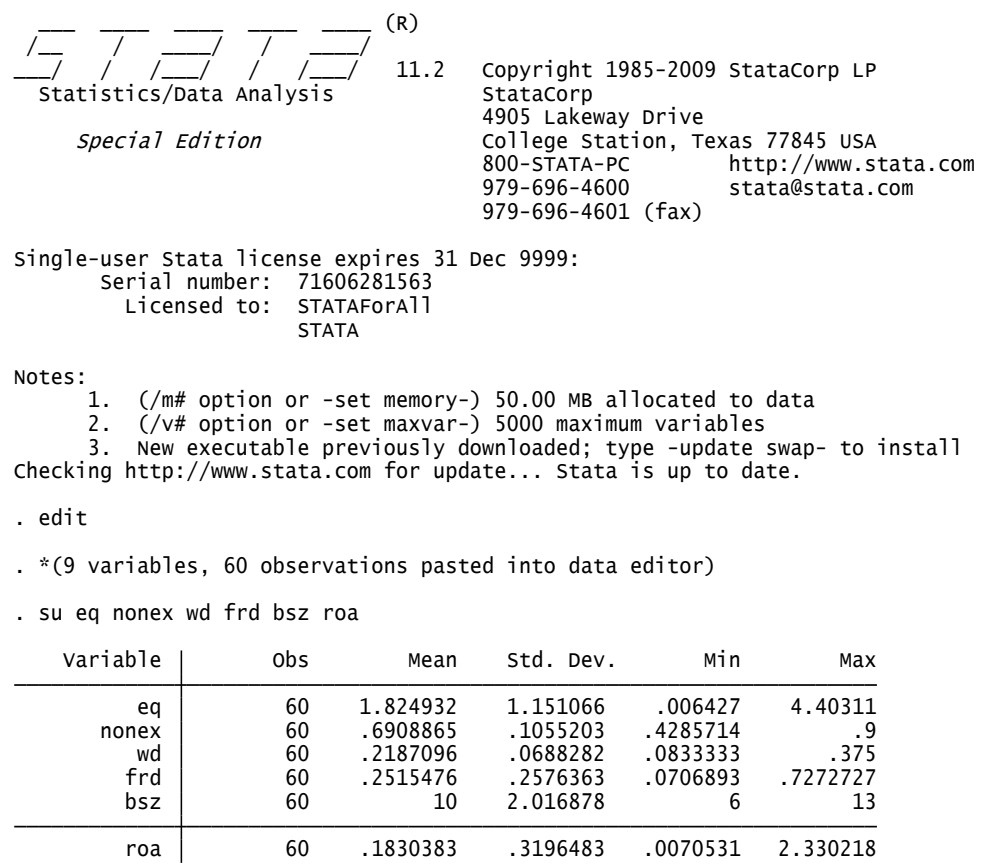

. su eq nonex wd frd bsz roa, detail

EQ

\begin{tabular}{|c|c|c|c|c|}
\hline $\begin{array}{r}1 \% \\
5 \% \\
10 \% \\
25 \%\end{array}$ & $\begin{array}{c}\text { Percentiles } \\
.006427 \\
.1108745 \\
.2503745 \\
.9132045\end{array}$ & $\begin{array}{r}\text { Sma11est } \\
.006427 \\
.087761 \\
.106798 \\
.114951\end{array}$ & $\begin{array}{l}\text { Obs } \\
\text { Sum of wgt. }\end{array}$ & $\begin{array}{l}60 \\
60\end{array}$ \\
\hline $50 \%$ & 1.857645 & Largest & $\begin{array}{l}\text { Mean } \\
\text { Std. Dev. }\end{array}$ & $\begin{array}{l}1.824932 \\
1.151066\end{array}$ \\
\hline $\begin{array}{l}75 \% \\
90 \% \\
95 \% \\
99 \%\end{array}$ & $\begin{array}{r}2.568865 \\
3.46803 \\
3.787045 \\
4.40311\end{array}$ & $\begin{array}{l}3.64554 \\
3.92855 \\
3.98062 \\
4.40311\end{array}$ & $\begin{array}{l}\text { Variance } \\
\text { Skewness } \\
\text { Kurtosis }\end{array}$ & $\begin{array}{l}1.324952 \\
.2072871 \\
2.155053\end{array}$ \\
\hline
\end{tabular}

NON-EX

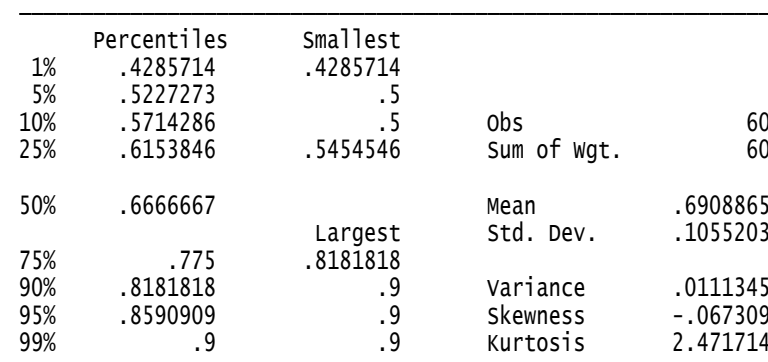

\begin{tabular}{rrrlr}
\multicolumn{5}{c}{ WD } \\
\\
\hline & Percenti1es & Sma11est & & \\
$1 \%$ & .0833333 & .0833333 & & \\
$5 \%$ & .1125 & .1 & obs & 60 \\
$10 \%$ & .1339286 & .1 & Sum of wgt. & 60 \\
$25 \%$ & .1666667 & .125 & & .2187096 \\
$50 \%$ & & & Mean & .0688282 \\
$75 \%$ & .2727273 & .3333333 & Std. Dev. & \\
$90 \%$ & .375 & .375 & Variance & .0047373 \\
$95 \%$ & .3541667 & .375 & Skewness & .3274394 \\
$99 \%$ & .375 & .375 & Kurtosis & 2.600192
\end{tabular}




\begin{tabular}{rcclr}
\hline & Percentiles & Smallest & & \\
$1 \%$ & .0706893 & .0706893 & & \\
$5 \%$ & .0804187 & .0804187 & & \\
$10 \%$ & .0804187 & .0804187 & obs & 60 \\
$25 \%$ & .1091067 & .0804187 & Sum of wgt. & \\
$50 \%$ & .1091067 & & Mean & .2515476 \\
& & Largest & Std. Dev. & .2576363 \\
$75 \%$ & .3807612 & .7272727 & & \\
$90 \%$ & .7272727 & .7272727 & Variance & .0663765 \\
$95 \%$ & .7272727 & .7272727 & Skewness & 1.168257 \\
$99 \%$ & .7272727 & .7272727 & Kurtosis & 2.407479
\end{tabular}

\begin{tabular}{|c|c|c|c|c|}
\hline \multicolumn{5}{|c|}{ BSZ } \\
\hline $\begin{array}{r}1 \% \\
5 \% \\
10 \% \\
25 \%\end{array}$ & $\begin{array}{r}\text { Percentiles } \\
6 \\
7 \\
7 \\
8\end{array}$ & $\begin{array}{r}\text { Smallest } \\
6 \\
6 \\
7 \\
7\end{array}$ & $\begin{array}{l}\text { obs } \\
\text { Sum of wgt. }\end{array}$ & $\begin{array}{l}60 \\
60\end{array}$ \\
\hline $\begin{array}{l}75 \% \\
90 \% \\
95 \% \\
99 \%\end{array}$ & $\begin{array}{r}10 \\
12 \\
12 \\
12.5 \\
13\end{array}$ & $\begin{array}{r}\text { Largest } \\
12 \\
13 \\
13 \\
13\end{array}$ & $\begin{array}{l}\text { Mean } \\
\text { Std. Dev. } \\
\text { Variance } \\
\text { Skewness } \\
\text { Kurtosis }\end{array}$ & $\begin{array}{r}10 \\
2.016878 \\
4.067797 \\
-.4125 \\
1.8875\end{array}$ \\
\hline \multicolumn{5}{|c|}{ ROA } \\
\hline $\begin{array}{r}1 \% \\
5 \% \\
10 \% \\
25 \%\end{array}$ & $\begin{array}{c}\text { Percentiles } \\
.0070531 \\
.015146 \\
.0275181 \\
.0581987\end{array}$ & $\begin{array}{l}\text { Sma1lest } \\
.0070531 \\
.0136076 \\
.0141426 \\
.0161493\end{array}$ & $\begin{array}{l}\text { Obs } \\
\text { Sum of wgt. }\end{array}$ & $\begin{array}{l}60 \\
60\end{array}$ \\
\hline $50 \%$ & .122328 & Largest & $\begin{array}{l}\text { Mean } \\
\text { std. Dev. }\end{array}$ & $\begin{array}{l}.1830383 \\
.3196483\end{array}$ \\
\hline $\begin{array}{l}75 \% \\
90 \% \\
95 \% \\
99 \%\end{array}$ & $\begin{array}{l}.1764203 \\
.3071423 \\
.6630288 \\
2.330218\end{array}$ & $\begin{array}{r}.59375 \\
.7323077 \\
.7571885 \\
2.330218\end{array}$ & $\begin{array}{l}\text { Variance } \\
\text { Skewness } \\
\text { Kurtosis }\end{array}$ & $\begin{array}{r}.102175 \\
5.374617 \\
35.49299\end{array}$ \\
\hline
\end{tabular}

. swi lk eq nonex wd frd bsz roa

Shapiro-Wilk w test for normal data

\begin{tabular}{r|rcrrr} 
Variable & obs & W & V & Z & Prob $>$ z \\
\hline eq & 60 & 0.96414 & 1.949 & 1.439 & 0.07513 \\
nonex & 60 & 0.98588 & 0.768 & -0.570 & 0.71576 \\
wd & 60 & 0.97907 & 1.138 & 0.278 & 0.39049 \\
frd & 60 & 0.67183 & 17.839 & 6.211 & 0.00000 \\
bsz & 60 & 0.95014 & 2.710 & 2.149 & 0.01581 \\
roa & 60 & 0.42415 & 31.301 & 7.423 & 0.00000
\end{tabular}

- correlate eq frd wd non_ex bsz roa (obs=60)

\begin{tabular}{r|rrrrrr} 
& eq & frd & wd & non_ex & bsz & roa \\
\hline eq & 1.0000 & & & & & \\
frd & -0.4235 & 1.0000 & & & & \\
wd & 0.0728 & -0.2512 & 1.0000 & & & \\
non_ex & -0.6319 & 0.5821 & -0.4373 & 1.0000 & & \\
bsz & -0.2500 & 0.4094 & 0.3956 & 0.2490 & 1.0000 & \\
roa & 0.2339 & -0.1409 & 0.7055 & -0.1795 & 0.5463 & 1.0000
\end{tabular}

reg eq frd wd non_ex bsz roa




. vif

\begin{tabular}{r|rr} 
Variable & VIF & $1 / \mathrm{VIF}$ \\
\hline wd & 2.67 & 0.374813 \\
roa & 2.56 & 0.390034 \\
bsz & 2.37 & 0.422414 \\
frd & 1.94 & 0.514370 \\
non_ex & 1.93 & 0.518640 \\
\hline Mean VIF & 2.29 &
\end{tabular}

. hettest

Breusch-Pagan / Cook-Weisberg test for heteroskedasticity

Ho: Constant variance

Variables: fitted values of eq

$\begin{array}{llr}\operatorname{chi2}(1) & 11.97 \\ \text { Prob }>\text { chi2 } & =0.0005\end{array}$

- xtset year id

panel variable: year (strongly balanced)

time variable: id, 1 to 6

delta: 1 unit

. xtreg eq frd wd non_ex bsz roa,

Random-effects GLS regression

Group variable: year

$\mathrm{R}-\mathrm{sq}$ : within $=0.6341$

between $=0.3084$

overa11 $=0.6236$

$\operatorname{corr}\left(u_{-} i, x\right)=0$ (assumed)

$\begin{array}{rlr}\text { Number of obs } & = & 60 \\ \text { Number of groups } & = & 10 \\ \text { Obs per group: } \min & = & 6 \\ \mathrm{avg} & = & 6.0 \\ \max & = & 6 \\ \text { Wald chi2(5) } & =89.47 \\ \text { Prob }>\text { chi2 } & = & 0.0000\end{array}$

\begin{tabular}{r|rrrrrr}
\hline eq & Coef. & Std. Err. & $\mathrm{z}$ & $\mathrm{P}>|\mathrm{z}|$ & [95\% Conf. Interva1] \\
\hline frd & .0061683 & .0383315 & 0.16 & 0.872 & -.06896 & .0812967 \\
wd & -.6374806 & .1332575 & -4.78 & 0.000 & -.8986605 & -.3763008 \\
non_ex & -.2911285 & .0436973 & -6.66 & 0.000 & -.3767736 & -.2054834 \\
bsz & -.0053594 & .0043015 & -1.25 & 0.213 & -.0137903 & .0030714 \\
roa & .1051741 & .0217781 & 4.83 & 0.000 & .0624899 & .1478584 \\
_cons & 1.310839 & .1252779 & 10.46 & 0.000 & 1.065299 & 1.556379 \\
\hline
\end{tabular}

. xtreg eq frd wd non_ex bsz roa,fe

\begin{tabular}{|c|c|c|}
\hline $\begin{array}{l}\text { Fixed-effects (within) regression } \\
\text { Group variable: year }\end{array}$ & $\begin{array}{l}\text { Number of obs } \\
\text { Number of groups }\end{array}$ & $\begin{array}{l}= \\
=\end{array}$ \\
\hline 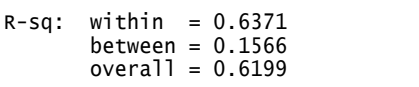 & $\begin{aligned} \text { obs per group: } & \min \\
& \text { avg } \\
& \max \end{aligned}$ & $\begin{array}{l}= \\
= \\
=\end{array}$ \\
\hline $\operatorname{corr}\left(u_{-} i, x b\right)=-0.0689$ & $\begin{array}{l}\mathrm{F}(5,45) \\
\text { Prob > F }\end{array}$ & $\begin{array}{l}= \\
=\end{array}$ \\
\hline
\end{tabular}

\begin{tabular}{r|rlrrrr}
\hline eq & Coef. & Std. Err. & $\mathrm{t}$ & $\mathrm{P}>|\mathrm{t}|$ & [95\% Conf. Interva1] \\
\hline frd & .0062515 & .0428537 & 0.15 & 0.885 & -.0800604 & .0925634 \\
wd & -.6472185 & .1521935 & -4.25 & 0.000 & -.9537519 & -.340685 \\
non_ex & -.2742149 & .0503581 & -5.45 & 0.000 & -.3756414 & -.1727884 \\
bsz & -.007727 & .0052043 & -1.48 & 0.145 & -.018209 & .0027549 \\
roa & .1167682 & .0248797 & 4.69 & 0.000 & .0666579 & .1668785 \\
_cons & 1.36295 & .1395292 & 9.77 & 0.000 & 1.081924 & 1.643976 \\
\hline sigma_u & .05129332 & \multicolumn{7}{c}{} \\
sigma_e & .20345275 & (fraction of variance due to u_i) & \\
rho & .05976293 & (fraction &
\end{tabular}

F test that a11 $u_{-} i=0: \quad F(9,45)=0.33 \quad$ Prob $>F=0.9619$ 
. xtreg eq frd wd non_ex bsz roa,re

Random-effects GLS regression

Group variable: year

$\begin{array}{lll}\text { Number of obs } & = & 60 \\ \text { Number of } & & 10\end{array}$

$\mathrm{R}-\mathrm{sq}$ : within $=0.6341$

between $=0.3084$

overa11 $=0.6236$

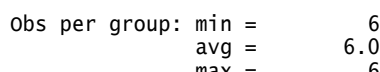

$\operatorname{corr}\left(\mathrm{u}_{-} \mathrm{i}, \mathrm{x}\right)=0$ (assumed)

$\begin{array}{ll}\text { Wald } \operatorname{chi2}(5) & =89.47\end{array}$

\begin{tabular}{r|rlrrrr}
\hline eq & Coef. & Std. Err. & z & P> $|z|$ & [95\% Conf. Interval] \\
\hline frd & .0061683 & .0383315 & 0.16 & 0.872 & -.06896 & .0812967 \\
wd & -.6374806 & .1332575 & -4.78 & 0.000 & -.8986605 & -.3763008 \\
non_ex & -.2911285 & .0436973 & -6.66 & 0.000 & -.3767736 & -.2054834 \\
bsz & -.0053594 & .0043015 & -1.25 & 0.213 & -.0137903 & .0030714 \\
roa & .1051741 & .0217781 & 4.83 & 0.000 & .0624899 & .1478584 \\
_cons & 1.310839 & .1252779 & 10.46 & 0.000 & 1.065299 & 1.556379 \\
\hline sigma_u & 0 & \multicolumn{5}{c}{} \\
sigma_e & .20345275 & (fraction of variance due to u_i) & \\
rho & 0 &
\end{tabular}

. xtreg eq frd wd non_ex bsz roa,re

Random-effects GLS regression

Group variable: year

$\mathrm{R}-\mathrm{sq}$ : within $=0.6341$

between $=0.308$

overa11 $=0.6236$

$\begin{array}{lll}\text { Number of groups } & = & 60\end{array}$

obs per group: $\begin{array}{rr}\min = & 6 \\ \operatorname{avg}= & 6.0\end{array}$

$\begin{array}{rr}\max = & 6\end{array}$

$\operatorname{corr}\left(u_{-} i, x\right)=0$ (assumed)

$\begin{array}{llr}\text { Wald chi2(5) } & \quad 89.47 \\ \text { Prob }>\text { chi2 } & =0.0000\end{array}$

\begin{tabular}{r|rlrrrr}
\hline eq & Coef. & Std. Err. & $\mathrm{z}$ & $\mathrm{P}>|\mathrm{z}|$ & [95\% Conf. Interva1] \\
\hline frd & .0061683 & .0383315 & 0.16 & 0.872 & -.06896 & .0812967 \\
wd & -.6374806 & .1332575 & -4.78 & 0.000 & -.8986605 & -.3763008 \\
non_ex & -.2911285 & .0436973 & -6.66 & 0.000 & -.3767736 & -.2054834 \\
bsz & -.0053594 & .0043015 & -1.25 & 0.213 & -.0137903 & .0030714 \\
roa & .1051741 & .0217781 & 4.83 & 0.000 & .0624899 & .1478584 \\
_cons & 1.310839 & .1252779 & 10.46 & 0.000 & 1.065299 & 1.556379 \\
\hline sigma_u & 0 & \multicolumn{7}{c}{} \\
sigma_e & .20345275 & (fraction of variance due to u_i) \\
rho & 0 &
\end{tabular}

. est store re

. hausman fe re

\begin{tabular}{|c|c|c|c|c|}
\hline & \multicolumn{2}{|c|}{ - Coefficients } & \multirow[b]{2}{*}{$\begin{array}{c}(b-B) \\
\text { Difference }\end{array}$} & \multirow[b]{2}{*}{$\begin{array}{c}\operatorname{sqrt}\left(d i a g\left(V \_b-V \_B\right)\right. \\
\text { S.E. }\end{array}$} \\
\hline & $\begin{array}{l}\text { (b) } \\
\mathrm{fe}\end{array}$ & $\begin{array}{l}\text { (B) } \\
\text { re }\end{array}$ & & \\
\hline & & & & \\
\hline wd & $\begin{array}{r}.0002310 \\
-.6472185\end{array}$ & $\begin{array}{r}.0001083 \\
-.6374806\end{array}$ & $\begin{array}{r}.0000832 \\
-.0097378\end{array}$ & .0735208 \\
\hline non_ex & -.2742149 & -.2911285 & .0169136 & .0250298 \\
\hline bsz & -.007727 & -.0053594 & -.0023676 & .0029294 \\
\hline roa & .1167682 & .1051741 & .011594 & .0120298 \\
\hline
\end{tabular}

$\mathrm{b}=$ consistent under Ho and $\mathrm{Ha}$; obtained from xtreg

$B=$ inconsistent under $\mathrm{Ha}$, efficient under $\mathrm{Ho}$; obtained from xtreg

Test: Ho: difference in coefficients not systematic

$\operatorname{chi2}(5)=(b-B) '\left[\left(V_{-} b-V_{-} B\right) \wedge(-1)\right](b-B)$

$\begin{aligned} \text { Prob }>\text { chi2 } & =\quad 0.9396\end{aligned}$

. xttest0

Breusch and Pagan Lagrangian multiplier test for random effects

eq[year,$t]=x b+u[y e a r]+e[y e a r, t]$

Estimated results:

\begin{tabular}{r|cc} 
& var & sd $=$ sqrt(var) \\
\hline eq & 1.324952 & 1.151066 \\
$\mathrm{e}$ & 1.268089 & 1.126095 \\
$\mathrm{u}$ & .0600092 & .2449678
\end{tabular}

Test: $\operatorname{var}(u)=0$

chibar2(01) $=0.06$

Prob $>$ chibar2 $=0.4002$ 
- xtreg eq frd wd non_ex bsz roa,robust

Random-effects GLS regression

Group variable: year

$\begin{array}{lll}\text { Number of obs } & = & 60\end{array}$

$\mathrm{R}-\mathrm{sq}$ : within $=0.6341$

between $=0.308$

overa11 $=0.6236$

$\begin{array}{rr}\text { obs per group: } \min = & 6 \\ \text { avg }= & 6.0\end{array}$

$\begin{array}{rr}\operatorname{avg}= & 6.0 \\ \max = & 6\end{array}$

$\operatorname{corr}\left(u_{-} i, x\right)=0$ (assumed)

$\begin{array}{ll}\text { wald } \operatorname{chi2}(5) & =353.66 \\ \text { Prob } & =0.0000\end{array}$

(Std. Err. adjusted for 10 clusters in year)

\begin{tabular}{|c|c|c|c|c|c|c|}
\hline eq & coef. & $\begin{array}{l}\text { Robust } \\
\text { std. Err. }\end{array}$ & z & $P>|z|$ & [95\% conf. & Interva1] \\
\hline $\begin{array}{r}\text { frd } \\
\text { wd } \\
\text { non_ex } \\
\text { bsz } \\
\text { roa } \\
\text { _cons }\end{array}$ & $\begin{array}{r}.0061683 \\
-.6374806 \\
-.2911285 \\
-.0053594 \\
.1051741 \\
1.310839\end{array}$ & $\begin{array}{l}.0219759 \\
.1158819 \\
.0172684 \\
.0048719 \\
.0286436 \\
.1330163\end{array}$ & $\begin{array}{r}0.28 \\
-5.50 \\
-16.86 \\
-1.10 \\
3.67 \\
9.85\end{array}$ & $\begin{array}{l}0.779 \\
0.000 \\
0.000 \\
0.271 \\
0.000 \\
0.000\end{array}$ & $\begin{array}{r}-.0369037 \\
-.8646049 \\
-.3249739 \\
-.0149081 \\
.0490337 \\
1.050132\end{array}$ & $\begin{array}{r}.0492404 \\
-.4103563 \\
-.2572831 \\
.0041893 \\
.1613146 \\
1.571546\end{array}$ \\
\hline $\begin{array}{r}\text { sigma_u } \\
\text { sigma_e } \\
\text { rho }\end{array}$ & $\begin{array}{r}0 \\
.20345275 \\
0\end{array}$ & (fraction & valla & e d & $u_{-} i$ ) & \\
\hline
\end{tabular}

